\title{
Local Self-Government and State Power: From the Constitutional Separation to the Unification (Based on the Russian Federation President's Messages)
}

\author{
Sergey Gennadevich Solovev ${ }^{1}$, Vachagan Vaghinakovich Sirekanyan ${ }^{1} \&$ Alexander Semenovich Kondratiev ${ }^{1}$ \\ ${ }^{1}$ South Ural State University (SUSU) (National Research University), Miass, Chelyabinsk region, Russia \\ Correspondence: Vachagan Vaghinakovich Sirekanyan, South Ural State University (SUSU) (National Research \\ University), 456304, 10A, 8 Iulya str., Miass, Chelyabinsk region, Russia. E-mail: vachagan@sirekanyan.com
}

Received: October 21, 2014 Accepted: November 15, 2014 Online Published: November 25, 2014

doi:10.5539/jpl.v7n4p171 URL: http://dx.doi.org/10.5539/jpl.v7n4p171

\begin{abstract}
The research subject of this article is conceptual-terminological, theoretical and logical elaboration concepts of local self-government, fixed in the Russian Federation current Constitution. We also consider the accessibility and clarity for Russian population to given constitutional concept of local self-government. Moreover the historical experience of practical implementation of its position on the Russian Federation territory is considered. The article analyzes the theoretical and practical problems associated with these problems.
\end{abstract}

Keywords: constitutional concept of local self-government, local self-government, Russian Federation Constitution

The question of optimal ratio of the local government and the state power was, is and will be one of the problems both in theory and practice of municipal construction in the Russian Federation. Nowadays the conceptual prime cause of these problems are the main ideas in section 2 of Article 3 and Article 12 of the Russian Federation Constitution dated 12 December, 1993, the regulatory basis for the following totality of ideas relating to the foundations of the constitutional system of the Russian Federation and forming a theoretical concept, which in modern Russia is supposed to build a system of local self-government:

1) The people exercise their power directly and through the bodies of state power and local self-government.

2) The local self-government bodies are not included in the system of state authorities (state power bodies).

3) The local government within their powers independently.

At the same time, it is important to consider the fact that this totality normative idea refers to the fundamentals of the constitutional system of the Russian Federation and represents the basic provisions, the legal foundation of the Russian local self-government. In this connection, the analysis of the conceptual-terminological elaboration of presented ideas are very important, within the Constitution as a legal act the norms on local government contained in section "Foundations of constitutional system" are hierarchically top section defining the basic content derived from its hierarchically lower the constitutional provisions on the organization of local self-government. Moreover, inasmuch as the legal acts in modern Russian legal system constitute a hierarchically ordered system (hierarchy), then the positions of all subsequent acts in the sphere of local self-government should arise from the above mentioned normative regulations fixedly attached in the section 2 of Article 3 and the Article 12 of the Russian Federation Constitution.

The marked theoretical concept is the ideological foundation of the Russian local government, and therefore, it should be:

1) immaculately conceptual and terminological, theoretically and logical elaborated

2) accessible and understandable for the Russian Federation population,

3) practically realizable.

\section{Conceptual-Terminological, Theoretical and Logical Elaboration Concepts}

However, the compliance with all of these requirements applied to this given concept causes lots of questions. It should be started with the fact that even conceptual careful study of its main term like "local self-government" 
causes the serious questions. As it pointed by D. B. Sergeev and many other municipal and legal right terminology researchers, the term of "local self-government" (although, as well as other municipal and legal right terms) is commonly used in various and alternative meanings sometimes since 90 's of XX century. It is used in municipal science and legislation for designation of the next various phenomena:

1) Foundations of Constitutional Order,

2) the population's activities directed to solution the local meaning questions,

3) fundamental principle of authority's organization,

4) nation's realization form of their authority,

5) citizen's rights,

6) organization's form of territorial public authority,

7) social arrangement optimization way,

8) organization's and service provision institute,

9) local governments,

10) municipal formation.

It's obvious to see that such "local self-government" term's multitasking reduce science and theoretical analyzing conception content of Russian local self-government's building greatly. It creates big problems for understanding its content not only for municipal building practitioners, but even for municipal building theorists. In order to understand what legislator, scientist or practitioner are talking about, it is necessary to research the context which this appropriate term is used in the frames of volume and notional forms enough. Thus, the "local self-government" term is sufficiently possible just taken out of context and use it for another meaning. As V. I. Vasiliev shows, while he forms juridical norms, the legislator has the right to use any eligible legal tools in this case. But, it should be pointed that its applying would be consecutive and accurate. The conceptual confusion is unacceptable, as well as the using of the same terms in different meanings, whereby the legal definitions' content is distorted and they stop their activities according to its assignment.

Besides of terminological incompletely, the pointed conception also causes objections from formal logic position. Designation of lower, local level of public authority through the using of "local self-government" term is submitted arguably. In case of logical intellection and considering of modern state scientists' works, self-government represents component of its handling system in Russian Federation, which also includes public authority system.

Essentially, the self-government represents social phenomenon that include three levels:

1) self-government at the Russian Federation level (state self-government) that includes all forms of direct population's desires at the state level;

2) self-government at the Russian Federation subjects level (regional self-government) that includes all forms of direct population's desires at their level;

3) self-government at municipal formations level (local self-government) that includes all forms of direct population's desires at their level.

Public imperious origins of Russian Federation controlling system realize appropriate system of Russian public authority consisting of the following levels:

1) Public state authority system at the Russian Federation level.

2) Public state authority system at the Russian Federation subjects level.

3) Public state authority system at municipal formations level.

Such modern mixture in analyzing conception's frames of "authority" and "self-government" concepts (section 2, Article 3 of RF Constitution) applying to democracy system in Russian Federation makes it logically contradictory and inexplicable not only for municipal legal right theorists but also for municipal building practice.

\section{Availability and Intelligibility the Conception for the Russia Federation Population}

The Russian Federation Constitution includes terminological, theoretical and logical fundamentals of local self-government, besides it must be written by language which will be comprehensible for everybody in Russian Federation. At the beginning of 20 century as for the organization of local self-administration in Great Britain S. 
Low considered that administration must be based on system of "mutual agreement" between population and state.

The president of Russia focused attention on this fact, when he was telling about prospects of development of Russian local self- government to the Federal Assembly on December 12, 2013 and noting that «... the local governance should be brings much benefits for each person... can gets really practicable help from the local governance... Let's look on this problems again to understand this situation in appropriate with good sense or in other words reference nowadays».

When we say about good sense we have to understand the fact, that the meaning of terms, which are used in the Russian Federation Constitution, should be clear for everyone especially for lawyer, government worker, political figure and journalist. It must be reached through study special academic subjects in schools and in higher educational institutions.

It is important to understand that the legislation as a whole and the Constitution in particular, represent one of the important tools of public authorities. In case the population does not understand the "character" and "spirit" of Constitution, then the society can't make appropriate sense of justice, and therefore the legislation won't be work as it is necessary. At the same time, we should remember that any constitution is written instrument that manages the development of state with appropriate constitutional provisions. The main ideas has been written in constitution through legal forms (legalese) must be consolidated in legal conscience of majority politically active population.

But the population perceives the Head of municipal government, from different elected official people, and the local government bodies as representatives of the government at the local level and makes them a claim connected with bankruptcy of enterprise, nonpayment wages in private enterprises, untimely transfer of federal pension, allowance and many other issues not within their competence. This fact was proved so the practice of municipal structuring in 90s in nowadays as many scientists' opinions which don't admit the official-juridical approach to the local self-government. They say that local self-government is the part of state power and artificial separation of local self-government from the state authority should be liquidated.

Summarizing all these we can establish a fact that Russian concept of constructing local self-government building had been written in constitution of Russian Federation and we deal with ideological ideas which are unknown for Russian traditions to resolve questions of local scale. In connection with this Russian mentality isn't able to make medium for building harmonious working system of local self-government based on this ideas.

\section{The Practical Realizability of the Concept}

Every nation in the world is characterized by their certain ideals and traditions for the local governance, solving the local issues which it carries through the centuries and sometimes through the millenniums.

The peoples living in the territory of the Russian Federation also having their own experience of local life is unique in many ways. At the same time, it should be remembered that management concepts, born and working out in one society may not always be used in another one.

The current post-Soviet statehood of Russia and the responding legal system, for securing the organization of local self-government, is just over 20 years. We must be realistic and understand that twenty years of experience is very short period of time to become a modern legal basis for local self-government. But it is practically instant of time from the perspective of world history.

On this basis it will be very presumptuous to talk about the concept of absolute infallibility for the organization of local self-government enshrined in the current Constitution of the Russian Federation. Probably, we should recognize the authors' right to errors in analyzed concept and right to subjection of something inherited of the past. However, it is important to give a real estimate, how successful was going to build the system of local government in Russia for those 20 years, whether the true life experience confirms the basic principles correctness of local self-government, declared in the RF Constitution.

Analyzing the position of many practitioners and theorists which analyze the current state of local government, it can be concluded that the successful development of the system of local self-government in Russia and correct basic principles of local self-government had been declared in the Constitution are highly questionable. For example, Avakyan S.A. casts doubt at all the existence of local government in Russia, V.I. Vasilyev and N.L. Peshin point to the lack of a clear concept development in local government; V.I. Fadeev pays attention to the fact that municipal authorities are loaded authority to address local issues, which often are not local but they have a public character; V.V. Tabolin notes negative experience "inculcate" Western European municipal model in our system of local government; R.V. Baboon observes the financial insecurity of local government and obvious discrepancy the 
local budget revenues volumes of their spending obligations ...

Critical analysis the implementation of the existing practice of the concept in local government can be continue long enough, but the purpose of this paper is not in this matter. It is important to understand if there are problems in the practical implementation of the local self-government current concept, it should deal with the fact, what is the main reason of such state of affairs. Because the problem can only be solved itself knowing its correct cause.

Last 20 years examining variety of sources constituting the Russian theory and multiple municipal practice of building the Russian local government we can suppose that the main reason for this variety of problems in the current system of local government is its separation from the constitutional system of government.

This conclusion confirmed by the analysis of legislation for foreign countries too, where local authorities generally are not strictly separated from the public authorities. In relation to European countries, this is partly explained by the fact that the European Charter of Local Self-Government does not provide the hard separation of self- government system.

Thereby, quite a long time in the theory of Municipal Law has put forward the idea with an enviable constancy that local governments should be an integral part of the national system with a certain share of autonomy to fulfill higher levels of government transferred authority. A.A. Kuznetsov, A.A. Balmasova S.I. Shishkin, M.A. Lavrik and many other scientists develop this thesis in his works, specializing in municipal and legal issues.

In view of the foregoing, it may be necessary to heed to the wishes on the Russian President's level, on the scientists' level specializing in the field of local government, on the level of ordinary Russian citizens and result in according with the requirements of common sense regulations on local government of the Russian Federation Constitution, as informational-algorithmic systems which purpose is to provide public administration and self-government in society succession of generations.

Concluding the consideration of the above problems, it should be focused on the fact that today we can state the problems in conceptual-terminological, theoretical and logical elaboration, accessible, understandable and practical implementation provisions the Constitutional concepts of local self-government, which gives reason for further detailed analysis and promotion of practical proposals to improve its content, which is planned to do in the framework of subsequent publications.

\section{References}

Atkinson, H., \& Wilks-Heeg, S. (1997). British Local Government since 1979: The end of an era (pp. 115). Sheffield Hallam university.

Avakyan, S. A. (2010). Is there a local self-government in Russia? Constitutionalist's reflections. Selected articles. Moscow.

Baboun, R. V. (2013). Problems and directions for financial base strengthening in local self-government. Local Law, 4(5), 45 .

Balmasova, A. A. (2007). Conceptual basis development of local government in Russia: questions of history, theory and legal regulation. Author's abstract of PhD in law. Kazan, pp. 19.

Ediazavod. (n. d.). Zlatoust metallurgists protesting against the cuts and unpaid wages. Retrieved March 23, 2014, from http://www.ediazavod.ru/articles/142727/

Editorial URSS. (2001). Losses and gaining in Russia in 90s. Vol. 2: Changing lives in the changing country: employment, earnings, consumption. Moscow: Editorial URSS.

Fadeev, V. I. (2009). The main problems of implementing the constitutional model of local self-government at the present stage. LEX RUSSICA, 2, 236.

Griffith, J. (1985). Foreword: Half a Century of Municipal Decline, 1935-1985 (pp. 11-12; Ed. bu M. Loughlin, D. Gelfand, K. Yound.) London,

Kimball, J. D. (1999). The Transfer of Power. Decentralization in Central and Eastern Europe. Budapest.

Kremlin. (2013, December 12). The Russian Federation President's messages to the Federal Assembly. Retrieved April 28, 2014, from http://www.kremlin.ru/transcripts/19825

Kuznetsov, A. A. (2003). Constitutional and legal aspects of local government development in European Charter of Local Self-Government. Author's abstract of PhD in law. Omsk, pp. 13.

Local Government (Scotland) Acts; Local Government (Wales) Acts. 1994., pp. 15.

Local Government. Aspects of Britain. 1996. London: HMSO Publications Centre, pp. 32. 
Low, S. (1904). The Governance of England (pp. 12). London.

Peshin, N. L. (2007). State Power and Local Self-government in Russia: Development problems of constitutional - legal model. Moscow.

Petrov, M. P. (2012). Executive power on the stage of Russian state modernization: Legal research experience: monograph (pp. 148-149). Moscow.

Sergeyev, D. B. (2012). Municipal Formation in the system of legal categories (monograph) (pp. 219-220). Ekaterinburg.

Shishkin, S. I., \& Lavrik, M. A. (2009). Local government: European standards and the Russian practice. Municipal Law, 1, 4.

Skuratov, Y. I. (1991). The self-government concept of people in USSR: the concept and content. Civil society and constitutional state: the preconditions for formation. Moscow.

Solomatkin, A. A. (1999). Local government in Russian rural settlements (Theory and Practice). Author's abstract of $\mathrm{PhD}$ in law. Chelyabinsk, pp. 8.

Solovev, S. G. (2003). Municipal-power institutions in the Russian Federation local self-government (pp. 104-106). St. Petersburg.

Tabolin, V. V. (2013). Revisiting the constitutional and legal essence of self-government in Russia. State Power and Local Self-government, 12, 38.

Timofeev, N. S. (2013). Municipal reform of the Russian Federation in the context of historical and international experience. Local Law, 4(5), 61.

Vanags, E., \& Vilka, I. (2000). Local Government in Latvia. Decentralization: Experiments and reforms (pp. 119-122). Local Governments in Central and Eastern Europe, London.

Vasilyev, V. I. (2004). Local Self-government : the fourth act of legislation. Journal of Russian Law, 1, 5.

Vasilyev, V. I. (2013). Some concepts of municipal law. Journal of Russian Law, 12.

Zhelvatykh, A. (n. d.). The independence of local authorities. Retrieved April 7, 2014, from http://www.perspektiva-miass.rf/index.php/munitsipalnyj-kodeks/133-vopros nezavisimosti-mestnoj-vlasti

\section{Copyrights}

Copyright for this article is retained by the author(s), with first publication rights granted to the journal.

This is an open-access article distributed under the terms and conditions of the Creative Commons Attribution license (http://creativecommons.org/licenses/by/3.0/). 